\title{
Hospital-Owned Retail Clinics in the United States: Operations, Patients and Marketing
}

\author{
Amer Kaissi $^{1 *}$ and Tom Charland ${ }^{2}$ \\ ${ }^{1}$ Department of Healthcare Administration, Trinity University, San Antonio, Texas, USA \\ ${ }^{2}$ Chief Executive Officer, Merchant Medicine LLC, Shoreview, Minnesota, USA
}

\begin{abstract}
Retail clinics are walk-in clinics located in grocery stores and retail pharmacies and providing care for minor conditions. Hospital systems have recently started owning and operating them. No studies have to our knowledge described hospital-owned clinics. In this paper, we assess the operational issues, types of conditions treated and types of marketing approaches used by hospital-owned retail clinics. Data on 19 health systems that own and operate retail clinics was collected by Merchant Medicine. Only 4 out of 19 hospital systems reported that their first owned retail clinic was operating at breakeven. About one third of the patients treated are cash-pay patients while half are covered by private health insurance plans. The clinics tend to focus on a few limited conditions such as upper respiratory infections, allergies, minor skin conditions, and physical exams and shots. A small minority of the patient population is very young (under 5) or very old (over 65), with the other age segments almost equally represented. Patients that visit the clinics seem to have heard about it especially through word of mouth. The health systems invest modestly in some marketing media such as print, radio and billboard advertising, Internet, direct mail and sponsoring of community events. Retail clinics can play an important role for hospital systems in the future, especially as part of a larger primary care strategy.
\end{abstract}

\section{Background}

Retail clinics are walk-in clinics located in grocery stores and retail pharmacies and providing care for minor conditions [1]. They have been in operation in the United States since 2000, with major growth taking place between 2006 and 2008. The current number of clinics (as of February 2013) has reached 1,425 clinics operating in most states [2]. A recent study found that retail clinics visits have increased fourfold from 2007 to 2009, with an estimated 5.97 million retail clinic visits in 2009 [3]. However, this only make up a small share (0.86\%) of overall visits (697 million visits) in the outpatient setting, comprised of 117 million visits to emergency departments and 577 million visits to physician offices annually [3].

The clinics are staffed by mid-level providers (nurse practitioners and physician assistants) with indirect physician supervision. The care provided is very convenient as the clinics are located in settings already visited multiple times per week by patients, and no appointments are necessary. "A menu of services is offered, with average fees of about $\$ 78$ per visit [4].

The majority of services provided are for ten minor conditions such as upper respiratory infections, urinary tract infections, minor skin conditions, flu shots and physical exams [5]. Research indicates that, contrary to what many skeptics claim, the care provided is of better or similar quality to that provided in traditional physician offices, while patient satisfaction is very high $[6,7]$.

Hospital systems represent new comers in the retail clinic scene, as most clinics were initially owned by investor-owned companies and retailers. However, the need for clinical expertise and legitimacy has driven some hospital systems to affiliate with retail clinics, or to own retail clinics while leasing space from a retailer [8]. According to Kaissi [1]: "For retail clinics that have linkages with a hospital system, the two common models of operations include a partnership/affiliation between the retail chain and the hospital system, or full ownership of the retail clinic by the hospital system. Under the first model, the retail chain owns and operates the clinics and makes decisions about the location of the clinics and the hiring of the clinicians. The hospital system, on the other hand, provides physician supervision, marketing and support for referrals. Under the ownership model, the hospital system owns the clinics either directly or through a separate legal entity created exclusively for this purpose. The system decides on the location of the clinics, employs the clinicians, and pays rent to the retail chain for the space provided.'The main strategic reasons behind the systems' associations with retail clinics are to increase market share through enhanced referrals to physician offices and hospitals, to become closer to consumers, and to experiment with non-traditional ways of delivering health care [8]. The total number of hospital systems currently involved in retail clinics (through affiliation or ownership) has reached 83 [2]. At the time of the survey, 262 retail clinics were owned by 83 hospital systems, out of 1,357 clinics (19\%). Given the recency of this trend, no studies have to our knowledge described the operations and services of these types of clinics. In this paper, we focus on hospital-owned clinics, and ask the following questions:

What operational issues are faced by hospital-owned retail clinics?

What types of patients are treated by hospital-owned retail clinics?

What types of marketing approaches are used by hospital-owned retail clinics?

\section{Methods}

We invited 55 representatives from hospital-owned retail clinic operators to participate in the study and sent them instructions on how to access the survey anonymously. A convenience sample of 20 systems was included in our study and representative from each system

*Corresponding author: Amer Kaissi, Ph.D, Associate Professor, Department of Healthcare Administration, Trinity University, San Antonio, Texas, USA, E-mail amer.kaissi@trinity.edu

Received February 26, 2013; Accepted March 22, 2013; Published March 25 2013

Citation: Kaissi A, Charland T (2013) Hospital-Owned Retail Clinics in the United States: Operations, Patients and Marketing. Primary Health Care 3: 130. doi:10.4172/2167-1079.1000130

Copyright: ( 2013 Kaissi A, et al. This is an open-access article distributed unde the terms of the Creative Commons Attribution License, which permits unrestricted use, distribution, and reproduction in any medium, provided the original author and source are credited. 
with direct retail clinic operational involvement filled out a 32-question survey covering various aspects of the clinics. Merchant Medicine, a leading research and consulting firm specializing in the field of walk-in medicine, developed the survey and collected the data. Responses were collected between October and December 2011 using Adobe Forms Central and de identification was used to encourage participation by hospital systems concerned about proprietary data being obtained by competitors. The final sample consisted of 19 systems since one of the representatives did not respond to a large number of questions. For questions asking about percentages, the respondents reported a percentage, and we calculated an average of all the percentages.

\section{Findings}

Table 1 includes the main descriptive variables. All the major geographical regions in the United States are represented, with the Midwest being the most represented ( 4 health systems). The mean number of retail clinics owned by a health system is 3.1 , and most of them own one $(30 \%)$ or two clinics $(30 \%)$. Three main management structures are used by the systems: management by the hospital system medical group (40\%); management by the hospital system outpatient services group (35\%); and management by a group within hospital system administration (25\%). The retail venues used by the systems consist mainly of "big box retailers" such as Walmart, Shopko or Meijer (70\%), with other venues including standalone drugstores (15\%), grocery stores such as Albertson's or Cub Foods (10\%) or drug store chains (5\%). The oldest clinics have been in operation for about 5 years (since December 2006) and the newest ones have opened just around the time the data was collected (October 2011).

\section{Operational Issues}

For ease of addressing operational issues, we asked the hospital systems to focus some of their answers on the first retail clinic owned by the system (Tables 2 and 3). Most of the hospital systems negotiated space with the retailer to have the clinic located in the front of the store (13 systems), with three negotiating a synergistic space right next to the pharmacy. In terms of clinic staffing, a physician is present on site

\begin{tabular}{|l|c|}
\hline Variable & $\mathbf{n}(\%)$ \\
\hline Region of Country: & $1(5.6 \%)$ \\
Great Lakes & $2(11.1 \%)$ \\
Mid Atlantic & $4(22.2 \%)$ \\
Midwest & $2(11.1 \%)$ \\
Northeast & $2(11.1 \%)$ \\
Northwest & $3(16.7 \%)$ \\
South & $1(5.6 \%)$ \\
Southeast & $3(16.7 \%)$ \\
\hline West & \\
\hline Management of clinics: & $5(26.3 \%)$ \\
Managed by a group within hospital system administration & $8(42.1 \%)$ \\
Managed by the hospital system medical group & $6(31.6 \%)$ \\
\hline Managed by the hospital system outpatient services group & \\
\hline Retail venue: & $13(68.4 \%)$ \\
Big Box retailer & $1(5.3 \%)$ \\
Drug store chain & $2(10.5 \%)$ \\
Grocery chain & $3(15.8 \%)$ \\
\hline Standalone drug store & \\
\hline Number of months first clinic owned by system: & 23.84 \\
Mean & 0 \\
Minimum & 57 \\
\hline Maximum & 3.21 \\
\hline Number of clinics owned by system: & 1 \\
Mean & 17 \\
Minimum & \\
Maximum & \\
\hline
\end{tabular}

Table 1: Descriptive Statistics $(n=19)$.

\begin{tabular}{|c|c|}
\hline Variable & n (\%) \\
\hline $\begin{array}{l}\text { Clinic In-store location*: } \\
\text { Back of the store } \\
\text { Either side of the store } \\
\text { Front of the store } \\
\text { Next to the pharmacy }\end{array}$ & $\begin{array}{c}2(10.5 \%) \\
1(5.3 \%) \\
13(68.4 \%) \\
3(15.8 \%)\end{array}$ \\
\hline $\begin{array}{l}\text { Number of MD hours per week*: } \\
\text { Mean } \\
\text { Minimum } \\
\text { Maximum }\end{array}$ & $\begin{array}{c}5.85 \\
0.00 \\
76.00\end{array}$ \\
\hline $\begin{array}{l}\text { Number of PA hours per week*: } \\
\text { Mean } \\
\text { Minimum } \\
\text { Maximum }\end{array}$ & $\begin{array}{c}20.54 \\
0.00 \\
80.00\end{array}$ \\
\hline $\begin{array}{l}\text { Number of NP hours per week* } \\
\text { Mean } \\
\text { Minimum } \\
\text { Maximum }\end{array}$ & $\begin{array}{c}63.50 \\
37.00 \\
100.00\end{array}$ \\
\hline $\begin{array}{l}\text { Front Desk Helper hours per week*: } \\
\text { Mean } \\
\text { Minimum } \\
\text { Maximum }\end{array}$ & $\begin{array}{c}54.94 \\
0.00 \\
80.00\end{array}$ \\
\hline $\begin{array}{l}\text { Clinic at breakeven*: } \\
\text { Yes } \\
\text { No }\end{array}$ & $\begin{array}{c}4(21.1 \%) \\
15(78.9 \%)\end{array}$ \\
\hline $\begin{array}{l}\text { Visits per hour to breakeven: } \\
\text { Mean } \\
\text { Minimum } \\
\text { Maximum }\end{array}$ & $\begin{array}{l}2.47 \\
2.00 \\
4.00\end{array}$ \\
\hline $\begin{array}{l}\text { Average collected revenue per visit: } \\
\text { Mean } \\
\text { Minimum } \\
\text { Maximum }\end{array}$ & $\begin{array}{l}\$ 55.00 \\
\$ 44.00 \\
\$ 72.00\end{array}$ \\
\hline $\begin{array}{l}\text { Visits per clinic per year: } \\
\text { Mean } \\
\text { Minimum } \\
\text { Maximum }\end{array}$ & $\begin{array}{c}6,674 \\
1,835 \\
28,184\end{array}$ \\
\hline $\begin{array}{l}\text { Average gross revenue per clinic: } \\
\text { Mean } \\
\text { Minimum } \\
\text { Maximum }\end{array}$ & $\begin{array}{c}\$ 340,482 \\
\$ 80,000 \\
\$ 765,000\end{array}$ \\
\hline
\end{tabular}

*For First Clinic Owned

Table 2: Operational Issues $(n=19)$

for about 6 hours per week on average, whereas the nurse practitioner spends 63.50 hours, the physician assistant spends about 20 hours, and the front desk helper (typically a medical assistant) spends around 55 hours. Fourteen respondents reported that their clinics are open 65-75 hours per week, whereas 5 systems reported that their clinics are open more than 65-75 hours per week."

From a volume/financial perspective, 15 hospital systems reported that their first clinic was not at breakeven. The average number of visits per hour to reach breakeven was reported to be 2.47 . The systems collected on average $\$ 55.00$ per visit, had 6,674 visits per year, and had a gross annual revenue of $\$ 340,482$ per clinic. In terms of payer mix, on average, the hospital systems reported that most of their patients are private PPO (42\%) or cash pay (32\%). Only a small majority of patients are covered by government programs such as Medicare (12\%) or Medicaid (7\%).

There was a wide variation in use of computers and electronic systems in the retail clinics among the health systems. While most of the systems do not have on-line registration (18 systems); the majority have the capacity to transmit patient encounters electronically by fax, e-mail or shared Electronic Medical Record to the primary care provider (17 systems). Some of the systems have computers in their clinics used for diagnosis/procedure coding; billing management; 


\begin{tabular}{|c|c|}
\hline Variable & n (\%) \\
\hline $\begin{array}{l}\text { Payer Mix (average): } \\
\% \text { Cash } \\
\% \text { Private PPO } \\
\% \text { Private HMO } \\
\% \text { Medicare } \\
\% \text { Medicaid } \\
\% \text { Workers' Comp }\end{array}$ & $\begin{array}{l}32.41 \% \\
41.69 \% \\
10.16 \% \\
12.20 \% \\
7.28 \% \\
0.19 \%\end{array}$ \\
\hline $\begin{array}{l}\text { Online Pre-registration currently available: } \\
\text { Yes } \\
\text { No }\end{array}$ & $\begin{array}{c}1(5.3 \%) \\
18(94.7 \%)\end{array}$ \\
\hline $\begin{array}{l}\text { Areas in which computers are used in clinic: } \\
\text { Diagnosis/procedure coding; Billing management; Tracking patient } \\
\quad \text { demographics; Medical records; Payroll management; Prescription } \\
\quad \text { ordering; Lab management } \\
\text { All of the above + Inventory management } \\
\text { Other }\end{array}$ & $\begin{array}{l}5(26.3 \%) \\
7(36.8 \%) \\
7(36.8 \%)\end{array}$ \\
\hline $\begin{array}{l}\text { Patient encounters transmitted electronically (fax, e-mail, shared } \\
\text { EMR) to primary care providers if requested } \\
\text { Yes } \\
\text { No }\end{array}$ & $\begin{array}{c}17(89.5 \%) \\
2(10.5 \%)\end{array}$ \\
\hline
\end{tabular}

tracking patient demographics; medical records; payroll management; prescription ordering and lab management (5 systems), as well as inventory management (7 systems).

\section{Conditions/Services}

We asked the respondents to indicate what fraction of their patients have a certain condition (Table 4). The most common conditions treated at their clinics are bronchitis, colds and flu's (average 19.71\%); sore throats (12.56\%); and camp/sport physicals (9.81\%). As for the patient population treated, most of them are in the $5-19$ years age group (average 20.00\%); the 20-34 years age group (23.13\%); and the 35-49 years age group $(21.31 \%)$. Only $5.9 \%$ of patients treated are younger than 5 years.

\section{Marketing}

Hospital systems regularly ask their patients how they heard about the retail clinics (Table 5). Respondents were asked to estimate these based on the results of their surveys. The majority of them report that is it by word of mouth (average 34.86\%). A few others hear about it from other sources (12.60\%), print advertising (12.00\%); and direct mail (7.86\%). The approaches used by the hospital systems to promote their clinics vary widely, with the most common media including direct mail, Internet Banner/website, print advertising, radio advertising, and sponsoring community events. The majority of the systems report that the in-store pharmacy is somewhat involved ( 9 systems) or very involved (4 systems) in the promotion of the retail clinic. The average total expenditure by health system on marketing is $\$ 16,701$ per year and $55 \%$ of the patients drawn by the retail clinic are new patients to the system.

\section{Discussion}

Hospital systems have taken the initiative in the retail clinic field in the last five years, with a significant number of systems developing their own clinics. As such, the system selects a retailer to work with, decides on the location of the clinic, employs the clinicians, and leases space from the retailer. In this paper, we examined the operational issues, patients treated, and marketing approaches used by hospital systems that own retail clinics.

Not surprisingly, the hospital systems negotiated a favorable location within the retail store for their clinics, especially in the front of the store and next to the pharmacy. These locations allow more visibility and foot traffic and are likely to result in increased awareness and visits. The hospital systems hire a medical director that is in charge of the clinic. However (except in few states), that physician is not required to be physically present at the clinic, and typically conducts chart reviews and is available for consultation from another location. The main providers used by the hospital systems to staff the clinics are nurse practitioners, and to a lesser extent, physician assistants. The clinics are also staffed by a front-desk helper that handles patient registration, billing and insurance follow-up.

An important finding was that only 4 out of 19 hospital systems reported that their first owned retail clinic was operating at breakeven. It is not clear what the profitability picture is like for non-hospital owned retail clinics, but anecdotal evidence suggests that it may not be too different [9-11]. Many operators, including health systems, assume that retail clinic operation is very straightforward and that building patient volume is relatively easy, and are very surprised when clinics underperform. This finding stresses the importance of understanding that the retail clinic business is different from other modes of healthcare delivery, and that different marketing and promotion approaches have to be used in order to grow a clinic. It also may indicate that some hospital systems do not view retail clinics as profit-making entities on their own, but rather as a downstream referral source and a release valve for overwhelmed primary care physicians and overcrowded emergency rooms [8].

About one third of the patients treated by the hospital-owned retail clinics are cash-pay patients. While it is not clear whether these patients are uninsured by choice or not, this finding suggests that retail clinics represent a relatively-low cost access point for some patients who prefer to pay $\$ 50-\$ 60$ out-of-pocket to take care of their immediate needs. In addition, about half of the patients are covered by private health insurance plans. While these patients may have the option of seeking care in a more traditional setting such as physician offices, they seek care in retail clinics out of convenience. While the majority of physician offices are open only during regular week-day business hours and have long waiting times, retail clinics are open on evenings and on weekends, require no appointments, and boast very short waiting times. In fact, Mehrotra and Lave recently reported that "approximately one quarter (28.9 percent) of weekday visits occurred during hours when physician offices are typically closed. Adding weekend visits to that proportion, we found that 44.4 percent of the retail clinic visits in our data occurred when physician offices are likely to be closed" [3].

\begin{tabular}{|l|c|}
\hline Variable & $\mathbf{( \% )}$ \\
\hline Conditions treated (Average): & \\
\% Bladder infections & $6.08 \%$ \\
\% Bronchitis, cold, flu & $19.71 \%$ \\
\% Ear infections & $8.48 \%$ \\
\% Sore throats & $12.56 \%$ \\
\% Pink eye, conjunctivitis, styes & $3.34 \%$ \\
\% Allergies & $8.69 \%$ \\
\% Minor injuries & $3.77 \%$ \\
\% Camp/sport physicals & $9.81 \%$ \\
\% Wellness screening & $4.93 \%$ \\
\% Skin conditions & $4.13 \%$ \\
\% Flu shots & $7.21 \%$ \\
\hline Other injections & $1.68 \%$ \\
\hline \% Under age 5 & \\
\% Age 5-19 & $5.89 \%$ \\
\% Age 20-34 & $20.00 \%$ \\
\% Age 35-49 & $23.13 \%$ \\
\% Age 50-64 & $21.31 \%$ \\
\hline
\end{tabular}

Table 4: Conditions/Services $(n=19)$. 
Citation: Kaissi A, Charland T (2013) Hospital-Owned Retail Clinics in the United States: Operations, Patients and Marketing. Primary Health Care 3: 130. doi:10.4172/2167-1079.1000130

\begin{tabular}{|c|c|}
\hline Variable & n (\%) \\
\hline $\begin{array}{l}\text { How customers heard about clinic (Average): } \\
\% \text { Word of mouth } \\
\% \text { Internet banner or website } \\
\% \text { Area employers } \\
\% \text { Insurance company } \\
\% \text { Direct mail } \\
\% \text { Print advertising } \\
\% \text { Radio advertising } \\
\% \text { Billboard advertising } \\
\% \text { TV advertising } \\
\% \text { Other }\end{array}$ & $\begin{array}{c}34.86 \% \\
7.07 \% \\
5.50 \% \\
5.38 \% \\
7.86 \% \\
12.00 \% \\
5.07 \% \\
4.80 \% \\
0.80 \% \\
12.60 \%\end{array}$ \\
\hline $\begin{array}{l}\text { Marketing approaches : } \\
\text { Direct Mail; Internet banner/website; Print advertising (newspaper, yellow }\end{array}$ & $1(5.3 \%)$ \\
\hline $\begin{array}{l}\text { pages) } \\
\text { Direct Mail; Internet banner/website; Print advertising (newspaper, yellow } \\
\text { pages); Billboard advertising; Sponsoring Community Events }\end{array}$ & $1(5.3 \%)$ \\
\hline $\begin{array}{l}\text { Direct Mail; Internet banner/website; Print advertising (newspaper, yellow } \\
\text { pages); Other }\end{array}$ & $3(15.8 \%)$ \\
\hline $\begin{array}{l}\text { Direct Mail; Internet banner/website; Print advertising (newspaper, yellow } \\
\text { pages); Radio advertising; Billboard advertising; Sponsoring Community } \\
\text { Events }\end{array}$ & $1(5.3 \%)$ \\
\hline $\begin{array}{l}\text { Direct Mail; Internet banner/website; Print advertising (newspaper, yellow } \\
\text { pages); Radio advertising; Billboard advertising; Sponsoring Community } \\
\text { Events; Other }\end{array}$ & $2(10.5 \%)$ \\
\hline $\begin{array}{l}\text { Direct Mail; Internet banner/website; Print advertising (newspaper, yellow } \\
\text { pages); Radio advertising; Other }\end{array}$ & $1(5.3 \%)$ \\
\hline $\begin{array}{l}\text { Direct Mail; Internet banner/website; Print advertising (newspaper, yellow } \\
\text { pages); Radio advertising; Sponsoring Community Events }\end{array}$ & $1(5.3 \%)$ \\
\hline $\begin{array}{l}\text { Direct Mail; Internet banner/website; Print advertising (newspaper, yellow } \\
\text { pages); Radio advertising; Sponsoring Community Events; Other }\end{array}$ & $1(5.3 \%)$ \\
\hline $\begin{array}{l}\text { Direct Mail; Internet banner/website; Print advertising (newspaper, yellow } \\
\text { pages); Radio advertising; TV advertising; Sponsoring Community Events; } \\
\text { Other }\end{array}$ & $1(5.3 \%)$ \\
\hline $\begin{array}{l}\text { Direct Mail; Print advertising (newspaper, yellow pages); TV advertising; } \\
\text { Sponsoring Community Events }\end{array}$ & $1(5.3 \%)$ \\
\hline $\begin{array}{l}\text { Internet banner/website } \\
\text { Internet banner/website; Print advertising (newspaper, yellow pages); Radio } \\
\text { advertising }\end{array}$ & $\begin{array}{l}1(5.3 \%) \\
1(5.3 \%)\end{array}$ \\
\hline $\begin{array}{l}\text { Internet banner/website; Print advertising (newspaper, yellow pages); Radio } \\
\text { advertising; Billboard advertising }\end{array}$ & $1(5.3 \%)$ \\
\hline $\begin{array}{l}\text { Internet banner/website; Print advertising (newspaper, yellow pages); Radio } \\
\text { advertising; Billboard advertising; Sponsoring Community Events }\end{array}$ & $1(5.3 \%)$ \\
\hline $\begin{array}{l}\text { Internet banner/website; Print advertising (newspaper, yellow pages); } \\
\text { Sponsoring Community Events }\end{array}$ & $1(5.3 \%)$ \\
\hline $\begin{array}{l}\text { Internet banner/website; Print advertising (newspaper, yellow pages); } \\
\text { Sponsoring Community Events; Other }\end{array}$ & $1(5.3 \%)$ \\
\hline $\begin{array}{l}\text { Average total annual expenditure on marketing: } \\
\text { Mean } \\
\text { Minimum } \\
\text { Maximum }\end{array}$ & $\begin{array}{l}\$ 16,701 \\
\$ 1,000 \\
\$ 50,000\end{array}$ \\
\hline $\begin{array}{l}\text { Percent of visits to clinic are from new patients: } \\
\text { Mean } \\
\text { Minimum } \\
\text { Maximum }\end{array}$ & $\begin{array}{l}54.41 \% \\
15.00 \% \\
95.00 \%\end{array}$ \\
\hline $\begin{array}{l}\text { Involvement of in-store pharmacy in clinic promotion } \\
\text { Not involved at all } \\
\text { Not very involved } \\
\text { Somewhat involved } \\
\text { Very involved }\end{array}$ & $\begin{array}{l}2(10.5 \%) \\
4(21.1 \%) \\
9(47.4 \%) \\
4(21.1 \%)\end{array}$ \\
\hline
\end{tabular}

Table 5: Marketing ( $n=19)$.

Our data suggest that in 17 out of 19 systems, patient encounters are transmitted electronically (fax, e-mail, shared EMR) to primary care providers if requested. This is an indicator that the hospital systems might be starting to appreciate the importance of connecting the clinics electronically with clinics and hospitals within the systems, and are therefore investing in information technology within the clinics as well as between the clinics and other in-system providers.

Similar to what have been reported in the literature about retail clinics in general, hospital-owned retail clinics tend to focus on a few limited conditions such as upper respiratory infections, allergies, minor skin conditions, and physical exams and shots. A small minority of the patient population is very young (under 5) or very old (over 65), with the other age segments almost equally represented. One implication is that parents of young children (under 5) are hesitant to use a retail clinic instead of a pediatrician, while parents of older children (5-19 years) are taking more advantage of the ease and convenience, especially when needing camp or sports physicals. It is important to note that all types of retail clinics (whether hospital-owned or not) can see children over 18 months of age. However, in some states like Massachusetts, retail clinics are not licensed to see children younger than two years of age. The 20-34 age group is the highest user group in retail clinic, which 
Citation: Kaissi A, Charland T (2013) Hospital-Owned Retail Clinics in the United States: Operations, Patients and Marketing. Primary Health Care 3: 130. doi:10.4172/2167-1079.1000130

is not surprising given that many people in that group do not have a primary care physician relationship.

Patients that visit hospital-owned retail clinics seem to have heard about the clinic especially through word of mouth. That explains why many hospital systems are emphasizing the importance of short wait times and excellent customer service for their clinic staff, as they realize that a satisfied patient is the best promotional tool. Having said that, the systems are also investing in other marketing media such as print, radio and billboard advertising, Internet, direct mail and sponsoring of community events, although with an average marketing budget of only $\$ 16,000$ per year. Hospital systems seem to be focusing their attention on converting one patient at a time, and on working synergistically with the retailers and their pharmacies to focus on in-store promotion. Given that more than half of the patients seen by the retail clinic are new patients to the system, the effort and money spent on promoting the clinics seem to be worth the investment, especially if these patients are appropriately captured and referred to other providers within the system.

The main limitation of this study relates to the generalizability of the results. Our samples of 19 health systems constitute a selective profile of systems that owned retail clinics at the time of the survey. Therefore, it should not be seen as a representative sample of all health systems that have engaged in clinic ownership.

\section{Conclusion}

Hospital-owned retail clinics have started to play a more important role, as hospital systems are starting to envision their long-term primary care strategies. In a healthcare system where primary care physician shortages are expected to increase, and where an additional 32 million people will have insurance coverage courtesy of the Affordable Care Act (ACA), retail clinics represent an additional access point that can be part of a larger infrastructure operating an Accountable Care Organization $(\mathrm{ACO})$ or a medical home. It remains to be seen whether the downstream savings and revenues are substantial enough, or whether retail clinics become a victim of the harsh reimbursement realities of the new era of healthcare delivery.

\section{Conflict of Interest}

Merchant Medicine is a research and consulting firm in the field of walk-in medicine. The company's primary focus is to help health systems and physician groups, as well as investors and suppliers, sort out their strategic options for convenient care. Merchant Medicine did not influence how the findings were reported or analyzed for this study.

\section{References}

1. Kaissi A (2012) Can Retail Clinics Save Primary Care? Primary Health Care Open Access 2.

2. Merchant Medicine, 2013.

3. Mehrotra A, Lave JR (2012) Visits to Retail Clinics Grew Fourfold From 2007 To 2009, Although Their Share of Overall Outpatient Visits Remains Low. Health Affairs.

4. Rudavsky R, Pollack CE, Mehrotra A (2009) The geographic distribution ownership, prices, and scope of practice at retail clinics. Ann Intern Med 151 315-320.

5. Mehrotra A, Wang MC, Lave JR, Adams JL, McGlynn EA (2008) Retail Clinics, Primary Care Physicians, and Emergency Departments: A Comparison of Patients' Visits. Health Affairs 27: 1273-1282.

6. Mehrotra A, Liu H, Adams JL, Wang MC, Lave JR, et al. (2009) Comparing Costs \& Quality of Care at Retail Clinics with that of other Medical Settings for 3 Common Illnesses. Ann Intern Med 151: 321-328.

7. Hunter LP, Weber CE, Morreale AP, Wall JH (2009) Patient Satisfaction with Retail Health Clinic Care. J Am Acad Nurse Pract 21: 565-570.

8. Kaissi A (2010) Hospital- Affiliated and Hospital-Owned Retail Clinics: Strategic Considerations and Operational Challenges. J Healthc Manag 55: 324-327.

9. Charatan F (2008) Walk-in Clinics at US retail Outlets run In to Financia Problems. BMJ 336: 1150-1151.

10. Tu HT, Cohen GR (2008) Checking up on Retail-Based Health Clinics: Is the Boom Ending? Issue Brief (Common Wealth Fund) 48: 1-11.

11. Yee CM (2008) Some Walk-In Clinics Closing After Boom. 